\title{
Hepatocellular Carcinoma pT4 TNM Finding v8
}

National Cancer Institute

\section{Source}

National Cancer Institute. Hepatocellular Carcinoma pT4 TNM Finding v8. NCI

Thesaurus. Code C134479.

Hepatocellular carcinoma with single tumor or multiple tumors of any size involving a major branch of the portal vein or hepatic vein, or tumor(s) with direct invasion of adjacent organs other than the gallbladder or with perforation of visceral peritoneum. (from AJCC 8th Ed.) 